\title{
CdS/CdTe Heterostructures for Applications in Ultra-Thin Solar Cells
}

\author{
Karla Gutierrez Z-B ${ }^{1}$ (D), Patricia G. Zayas-Bazán ${ }^{1}$ (D), Osvaldo de Melo ${ }^{2,3}$, \\ Francisco de Moure-Flores ${ }^{4}$, José A. Andraca-Adame ${ }^{5}$, Luis. A. Moreno-Ruiz ${ }^{5}$, \\ Hugo Martínez-Gutiérrez ${ }^{5}$, Salvador Gallardo ${ }^{6} \mathbb{D}$, Jorge Sastré-Hernández ${ }^{1}$ and \\ Gerardo Contreras-Puente ${ }^{1, *}$ \\ 1 Escuela Superior de Física y Matemáticas, Instituto Politécnico Nacional, \\ Ciudad de México C.P. 07738, Mexico; karlazb@gmail.com (K.G.Z-B); \\ patriciagzb2006@gmail.com (P.G.Z.-B.); sastrehj@hotmail.com (J.S.-H.) \\ 2 Facultad de Física, Universidad de La Habana, Colina Universitaria, La Habana C.P. 10400, Cuba; \\ odemelo@gmail.com \\ 3 Departamento de Materiales de Baja Dimensionalidad, Instituto de Investigaciones en Materiales, \\ Universidad Nacional Autónoma de México, Ciudad de México C.P. 04510, Mexico \\ 4 Facultad de Química, Materiales-Energía, Universidad Autónoma de Querétaro, \\ Querétaro C.P. 76010, Mexico; fcomoure@hotmail.com \\ 5 Centro de Nanociencias y Micro y Nanotecnologías del IPN, Ciudad de México C.P. 07738, Mexico; \\ andraca1@yahoo.com.mx (J.A.A.-A.); lmorenor@ipn.mx (L.A.M.-R.); humartinez@ipn.mx (H.M.-G.) \\ 6 Departamento Física, Cinvestav-IPN, Ciudad de México C.P. 07360, Mexico; sgh1977@hotmail.com \\ * Correspondence: gscp1953@gmail.com; Tel.: +521-554-133-3209
}

Received: 18 August 2018; Accepted: 17 September 2018; Published: 20 September 2018

\begin{abstract}
The preparation of ultra-thin semi-transparent solar cells with potential applications in windows or transparent roofs entails several challenges due to the very small thickness of the layers involved. In particular, problems related to undesired inter-diffusion or inhomogeneities originated by incomplete coverage of the growing surfaces must be prevented. In this paper, undoped $\mathrm{SnO}_{2}$, $\mathrm{CdS}$, and CdTe thin films with thickness suitable for use in ultra-thin solar cells were deposited with a radiofrequency (RF) magnetron sputtering technique onto conductive glass. Preparation conditions were found for depositing the individual layers with good surface coverage, absence of pin holes and with a relatively small growth rate adapted for the control of very small thickness. After a careful growth calibration procedure, heterostructured solar cells devices were fabricated. The influence of an additional undoped $\mathrm{SnO}_{2}$ buffer layer deposited between the conductive glass and the $\mathrm{CdS}$ window was studied. The incorporation of this layer led to an enhancement of both short circuit current and open circuit voltage (by 19 and 32\%, respectively) without appreciable changes of other parameters. After the analysis of the cell parameters extracted from the current-voltage (I-V) curves, possible origins of these effects were found to be: Passivation effects of the $\mathrm{SnO}_{2} / \mathrm{CdS}$ interface, blocking of impurities diffusion or improvement of the band alignment.
\end{abstract}

Keywords: sputtering; semiconductors; thin films; optical materials and properties; solar energy materials

\section{Introduction}

With an expected efficiency above $20 \%$ [1], conventional, highly absorbing, and non-transparent $\mathrm{CdS} / \mathrm{CdTe}$ thin film solar cells are among the most promising photovoltaic devices for terrestrial purposes. A typical solar cell uses a $10 \mu \mathrm{m}$ CdTe absorber layer which has a nearly optimal band gap and a high absorption coefficient [2]; a thin CdS film serves as window and n-type partner. Although 
the processing of these two materials can be carried out with some different physical or chemical methods [3,4], the sputtering technique has unique advantages, as for example, allowing sequential depositions without vacuum breaking, good control of small growth rates (particularly useful for growing ultra-thin layers) and no wastes generation.

The use of partially transparent CdS/CdTe ultra-thin (UT) solar cells has been the focus of recent research efforts due to the feasibility of their application in different kinds of windows or roofs [5]. For these applications, UT cells should entail: (i) Efficiencies as high as possible (taking into account that a significant part of the radiation is obviously not absorbed in the cell); (ii) aesthetics, as to be compatible with building, sunroofs, etc.; (iii) adequate optical properties in the visible region as demanded by standard regulations tinted windows; and (iv) comfortable indoor buildings environment. These cells are fabricated with the absorber layer whose thickness is thinner than the length of optical absorption and carrier diffusion leading to the desired partial transparency and enhanced carrier collection.

The growth of heterostructures composed by very thin films entails challenges mainly related to thickness uniformity and uncompleted surface coverage. In this paper, RF sputtering was used for the growth of ultra-thin $\mathrm{SnO}_{2}, \mathrm{CdS}$, and CdTe films with thickness optimized for the requirements of UT solar cell. Heterostructures combining these materials were prepared as well. To illustrate the application of these structures, solar cell devices were fabricated onto conductive glass substrates by adding $\mathrm{Au} / \mathrm{Cu}$ back contacts. Since the insertion of buffer layers has proven to increase the efficiency and the reproducibility of thick solar cells [6], we studied the influence of an undoped $\mathrm{SnO}_{2}$ $\left(\mathrm{u}-\mathrm{SnO}_{2}\right)$ buffer layer in the performance of our UT cells. $\mathrm{u}-\mathrm{SnO}_{2}$ layers have been previously prepared by different techniques such as chemical reactive evaporation [7], chemical vapor deposition [8] or sputtering [9] as per our knowledge, there are no reports on the use of these buffer layers in UT solar cells. Possible origins of the observed influence of the buffer layer in the photovoltaic performance of the devices are explored in this work by the analysis of the cell parameters extracted from the current-voltage curves.

\section{Materials and Methods}

$\mathrm{CdS}, \mathrm{u}-\mathrm{SnO}_{2}$, and CdTe UT films were deposited with a sputtering system (model V3, Intercovamex, Mexico City, Mexico) equipped with three magnetrons and corresponding 3-in diameter targets (purity of 99.99\%). Conductive soda-lime glasses (SLG) $/ \mathrm{SnO}_{2}: \mathrm{F} \mathrm{(2} \mathrm{nm)} \mathrm{(in} \mathrm{what} \mathrm{follows,} \mathrm{TEC15,}$ according to the manufacturer nomenclature, Pilkington, St Helens, United Kingdom) were used as substrates. Before depositing the film, the substrates were ultrasonically cleaned with a warm neutral detergent solution, rinsed with deionized water and isopropyl alcohol, and dried with nitrogen. Deposition was carried out in an Ar atmosphere while maintaining a fixed substrate temperature and RF-power of $250^{\circ} \mathrm{C}$ and $80 \mathrm{~W}$, respectively. According to previous growth rate calibration (see Figure S1 in the Supplementary Material), deposition times were $50 \mathrm{~min}$ for $\mathrm{u}-\mathrm{SnO}_{2}$ and $\mathrm{CdS}$ and $4 \mathrm{~h}$ for $\mathrm{CdTe}$. With these deposition times, the thicknesses of 35, 70 and $650 \mathrm{~nm}$ were obtained for $\mathrm{u}-\mathrm{SnO}_{2}, \mathrm{CdS}$, and CdTe, respectively. The thickness of the CdTe layer was selected to balance acceptable optical transmittance (as required for UT solar cells), good homogeneity, and complete surface coverage. Using the growth parameter determined for the individual layers, two different heterostructures were prepared: TEC15/u-SnO $/ \mathrm{CdS} / \mathrm{CdTe}$ and TEC15/CdS/CdTe. With the aim of illustrating the application of these heterostructures, solar cell devices were fabricated with both structures by adding a $\mathrm{Cu} / \mathrm{Au}$ back contact evaporated onto the CdTe surface.

Optical transmission spectra were measured with a Lambda 35 ultraviolet-visible spectrophotometer (Perkin-Elmer, Mexico City, Mexico) in the range from 330 to $1100 \mathrm{~nm}$. X-Ray diffractograms were taken with a X'Pert PRO PANalytical diffractometer (Almelo, Netherlands) in fixed grazing incidence angle at room temperature and using $\mathrm{Cu}-\mathrm{K} \alpha$ radiation $(\lambda=1.54056 \AA)$. Raman spectra were measured with a Labram HR800 (Horiba Jobin Yvon, Kyoto, Japan) equipment, with an excitation line of $532 \mathrm{~nm}$. Scanning electron microscopy (SEM) images and energy dispersed spectroscopy (EDS) were obtained with a JSM 7800F JEOL system (Kyoto, Japan). For cross-sectional imaging, samples were prepared by 
polishing and plasma erosion of the broken edge of cut samples. The thicknesses of the films were measured using a profilometer Ambios XP-100 (California, United States). Compositional profiles were obtained on a "time of flight" secondary ion mass spectrometer (SIMS, ION TOF, New York, NY, United States); a $150 \mu \mathrm{A}$ Cs primary beam with energy of $2 \mathrm{KeV}$; an area of $400 \mu \mathrm{m}^{2}$ was used. The room temperature I-V curves were obtained with an Oriel solar simulator Newport model 91160 whose illumination area is $25 \mathrm{~cm}^{2}$ using an AM1.5G filter and a radiation intensity of $100 \mathrm{~mW} / \mathrm{cm}^{2}$.

\section{Results and Discussion}

\subsection{Individual Layers}

With the final objective of inserting them in the heterostructures, we proceeded to characterize the individual layers in terms of their morphology, crystalline structure, and chemical composition. Figure 1 shows the transmittance spectra of the TEC15 substrate, $\mathrm{u}-\mathrm{SnO}_{2}, \mathrm{CdS}$, and CdTe films in the range from 330 to $1100 \mathrm{~nm}$ (the sputtered films were measured with the TEC15 substrate as the baseline). As can be observed, $\mathrm{u}-\mathrm{SnO}_{2}$ and $\mathrm{CdS}$ films presented an average optical transmission of $96 \%$ and $84 \%$, respectively, when evaluated in a transmission range of 400 to $700 \mathrm{~nm}$. The CdTe layer had an average transmittance of $15 \%$, which is expected to dominate the entire heterostructure device composed of the different films. This value is comparable the one typically reported in the UT solar cells industry. (For example, Sun Well Solar Company sells semi-transparent PV modules with a transmittance of $13.5 \%$ in the visible range [10]). No appreciable modifications were observed in the transmission spectra (see supplementary material) from the full heterostructures with and without the buffer layer. This was expected due to the transparency of the $\mathrm{u}-\mathrm{SnO}_{2}$ layer (see Figure $\mathrm{S} 2$ in the Supplementary Material).

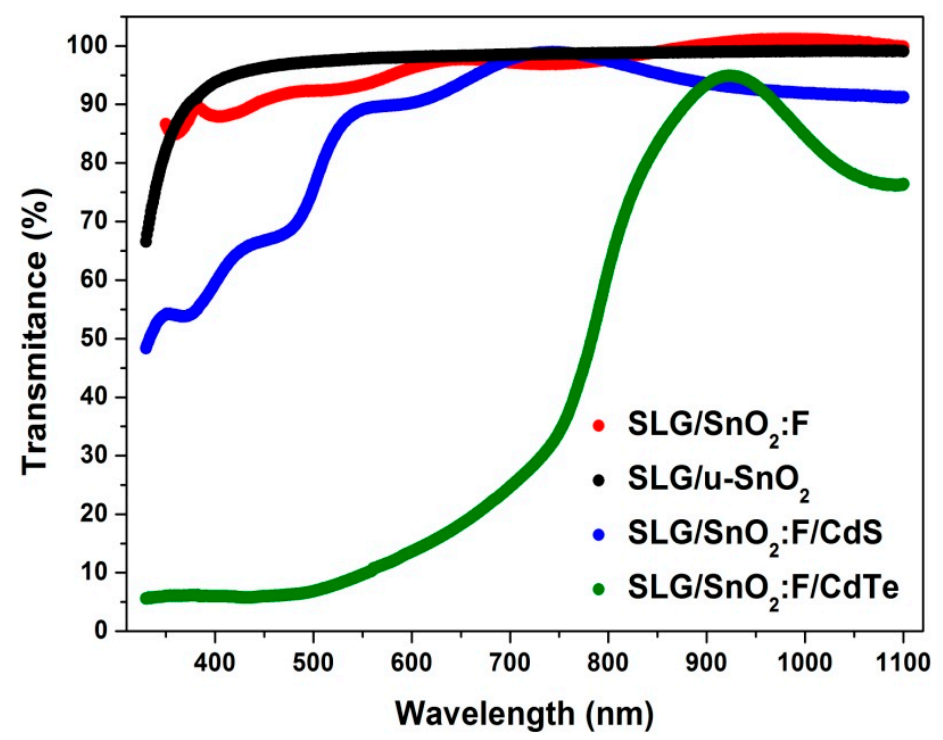

Figure 1. Transmission spectra for the different layers studied in this paper.

The band gaps of the deposited materials were calculated using the low transmission region of the UV-VIS spectra, where a clear absorption edge is noted (Figure 2). $(\alpha \mathrm{h} v)^{\mathrm{n}} \mathrm{vs}$. hv Tauc plots, where $\alpha$ and $\mathrm{h} v$ represent the absoption coefficient and photon energy, respectively, with $\mathrm{n}=2$ (as corresponds with direct allowed transitions) were used for these calculations. The band gap values obtained for $\mathrm{u}-\mathrm{SnO}_{2}, \mathrm{CdS}$, and $\mathrm{CdTe}$ were 3.6, 2.4 and $1.57 \mathrm{eV}$, respectively, which are close to those reported in the literature [11-13]. 

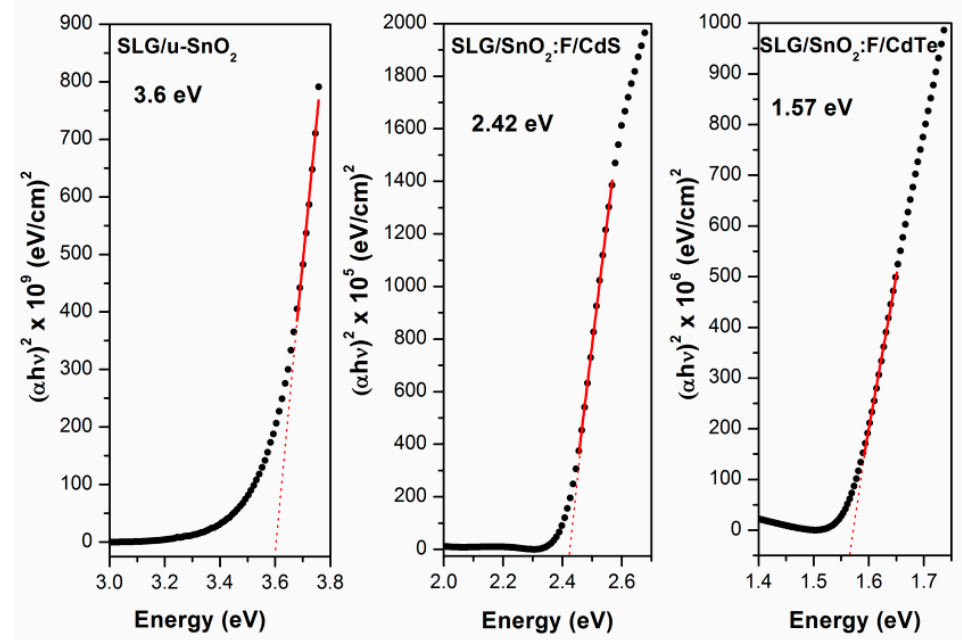

Figure 2. Tauc plots used for band gap calculation of the different materials forming the heterostructure. The extrapolation of the $(\alpha \mathrm{hv})^{2}$ vs. E linear region fitting is also shown.

Diffractograms for the different samples are shown in Figure 3. For $\mathrm{SnO}_{2}$, only peaks corresponding to the tetragonal phase (identified as $\mathrm{T}$ in the diffractogram) are observed. In the case of CdS, all peaks correspond to the hexagonal phase (PDF 00-041-1049) and are identified as H. On the other hand, CdTe film reveals the presence of a cubic phase (PDF 00-015-0770) (marked as C in the diffractogram). All other peaks in the CdS and CdTe diffractograms, highlighted with dashed lines, correspond to the $\mathrm{SnO}_{2}: \mathrm{F} /$ soda-lime glass substrate as indicated.

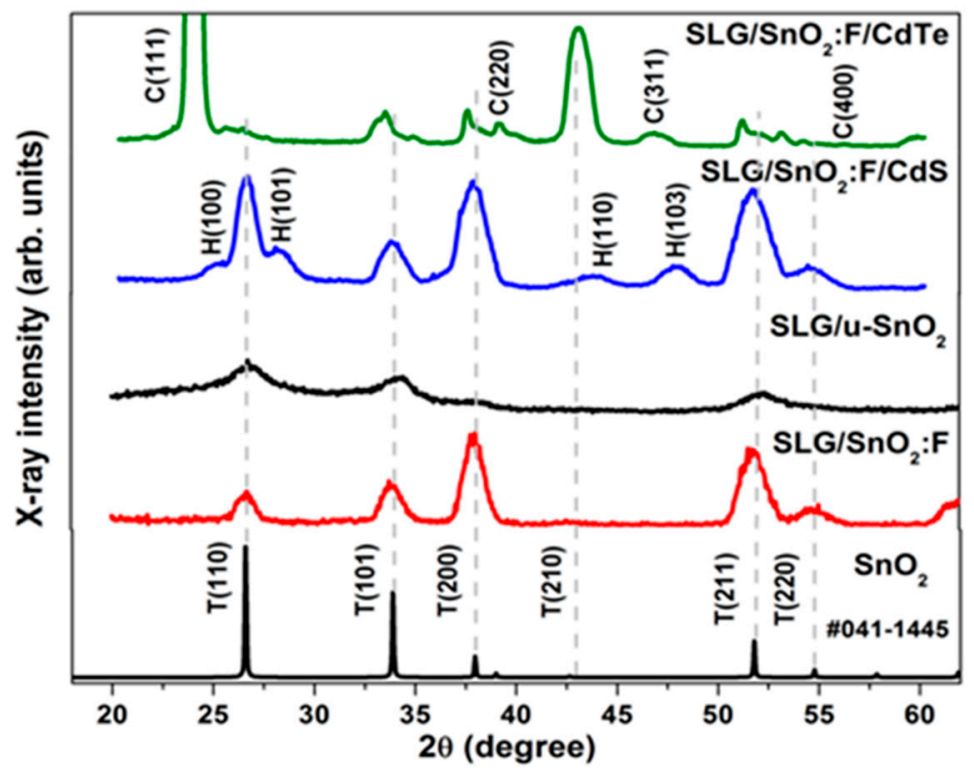

Figure 3. XRD pattern for $\mathrm{SnO}_{2}, \mathrm{CdS}$, and CdTe deposited onto TEC15. T, C and $\mathrm{H}$ stand for tetragonal, cubic, and hexagonal phases.

Raman spectra of the $\mathrm{u}-\mathrm{SnO}_{2}$ film and substrate are shown in Figure 4a. Features at 120, 298, 475, 627, 690 and $764 \mathrm{~cm}^{-1}$, corresponding to characteristic $\mathrm{SnO}_{2}$ Raman phonons, are observed [14]. Other peaks originating in the soda-lime glass [15] substrate were denoted by + . 

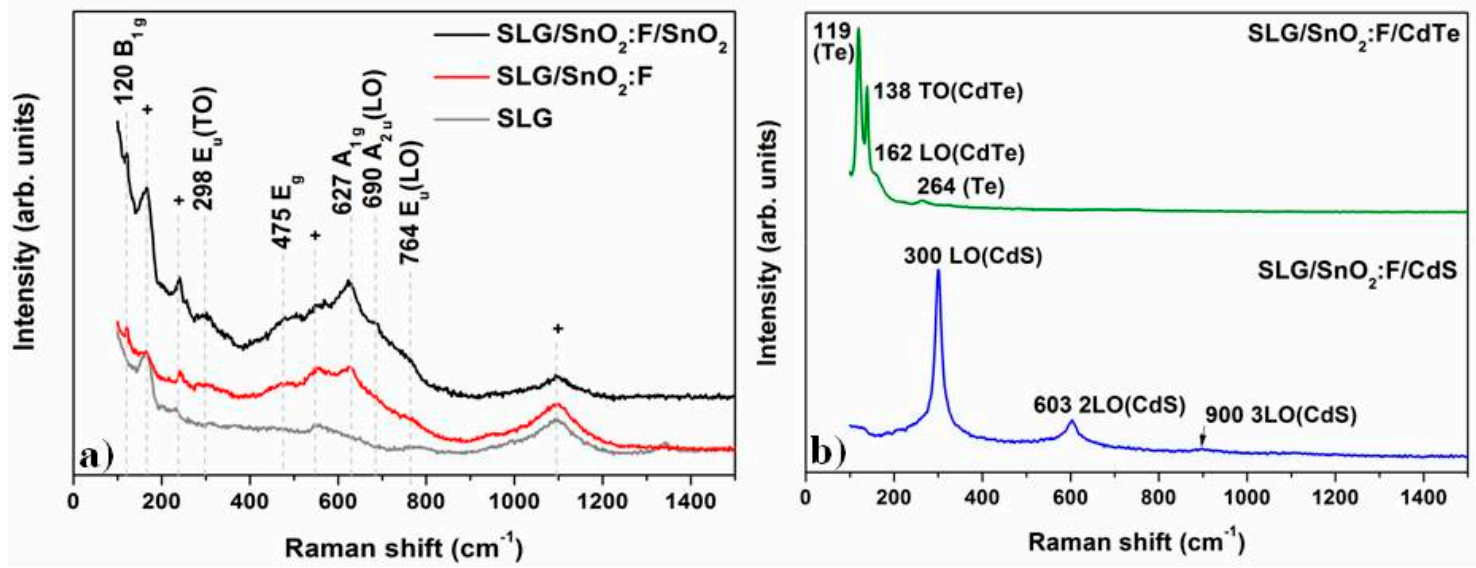

Figure 4. Raman spectra for the samples; (a) $\mathrm{SnO}_{2}$ sample and the substrate and (b) $\mathrm{CdS}$ and CdTe samples.

Raman spectra of CdS and CdTe are shown in Figure $4 \mathrm{~b}$. For CdS, the peak at $300 \mathrm{~cm}^{-1}$ corresponds with the longitudinal optical (LO) phonon mode, while peaks at 603 and $900 \mathrm{~cm}^{-1}$ can be assigned to the harmonics $2 \mathrm{LO}$ and 3LO, respectively [16]. In the case of CdTe, the peaks located at 138 and $162 \mathrm{~cm}^{-1}$, correspond to the transverse optical (TO) and LO CdTe $\Gamma$-phonons modes, respectively. The peaks in 119 and $264 \mathrm{~cm}^{-1}$ belongs to an undetermined tellurium phase present in the film [17].

Figure 5 shows representative top view SEM images of $\mathrm{u}-\mathrm{SnO}_{2}, \mathrm{CdS}$, and CdTe films. It is remarkable the good surface coverage and the absence of pinholes (as far as the magnification and focus of the images allow) despite the small thickness of the films. In-plane average grain sizes measured from this SEM images were 160, 158 and $177 \mathrm{~nm}$ for $\mathrm{u}-\mathrm{SnO}_{2}, \mathrm{CdS}$, and CdTe, respectively (see Figure S3 in the Supplementary Material).

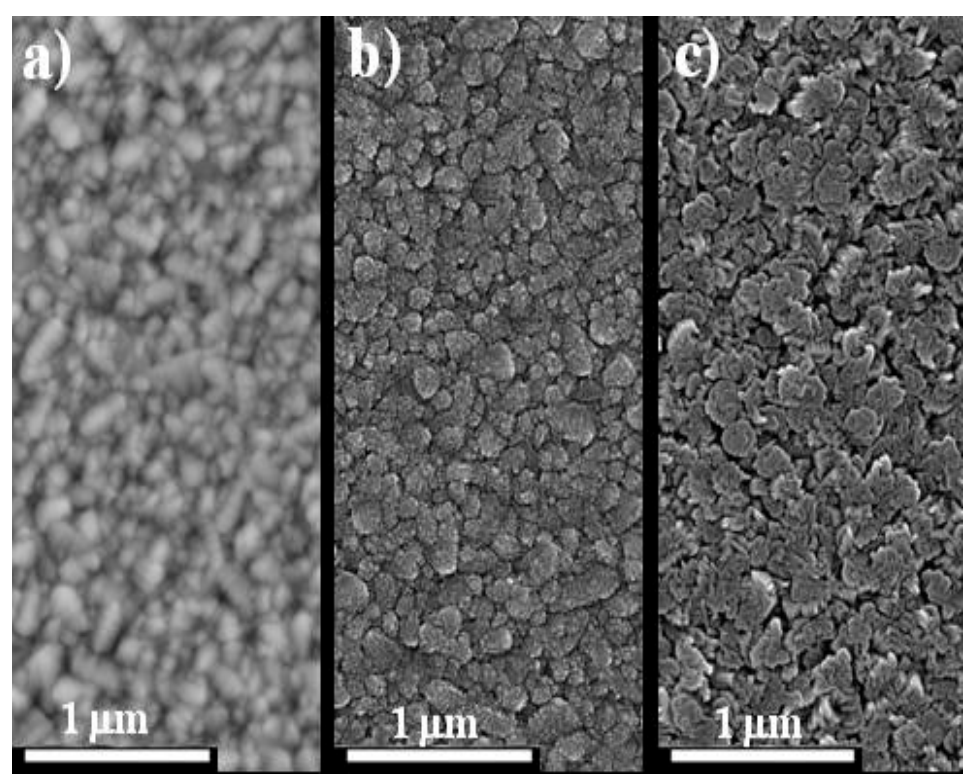

Figure 5. Top view SEM images of the individual layers. (a) $\mathrm{u}-\mathrm{SnO}_{2} ;$ (b) CdS; and (c) CdTe films.

\subsection{Heterostructures}

With the same growth parameters used for the individual layers, the heterostructures were fabricated. The schematic representation of the structure is shown in Figure 6a. Composition profiles for a typical heterostructure, determined with EDS linear mapping along the cross-section of the 
samples and SIMS are shown in Figure 6b,c, respectively. The obtained profiles correspond well with the cross-section SEM micrograph shown in Figure $6 \mathrm{~d}$, where relatively abrupt interfaces can be noted. A columnar growth is evident in the CdTe layer.

a)
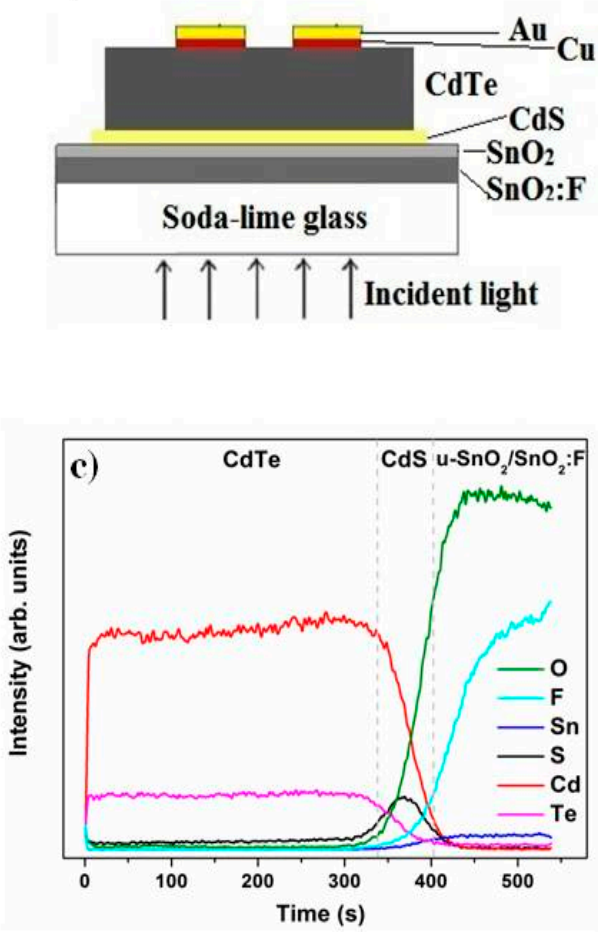
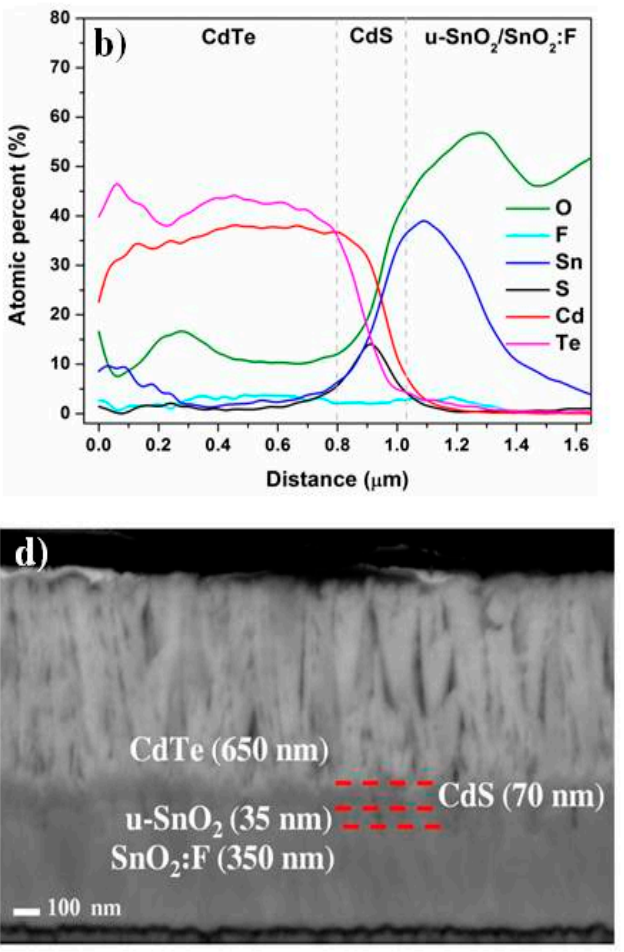

Figure 6. (a) The diagram of the solar cell with the buffer layer. Composition profiles of the heterostructures; (b) EDS linear map and (c) SIMS; (d) Cross-section SEM image.

To illustrate the application of the heterostructures, a solar cell was fabricated in the superstrate configuration by depositing $\mathrm{Cu} / \mathrm{Au}$ back contacts unto the CdTe surface as indicated in Figure 6a. (The solar cell without buffer layer was very similar; except for the $\mathrm{u}-\mathrm{SnO}_{2}$ layer).

Dark and illuminated I-V curves of the two heterostructures (with and without $\mathrm{u}-\mathrm{SnO}_{2}$ layer) are displayed in Figure 7. The device parameters of the solar cell extracted from these curves are summarized in Table 1. Although the device characteristics were not optimized, a clear photovoltaic (PV) effect is observed. The cell with the added $\mathrm{u}-\mathrm{SnO}_{2}$ layer presents a better PV performance. While fill factor (FF) values were practically the same for both devices, the short circuit current (Isc) and open circuit voltage (Voc) increased by 19 and 32\%, respectively, for the cell with the added $\mathrm{u}-\mathrm{SnO}_{2}$ layer. This presents an efficiency of $\eta=3.75 \%, 1.7$ times higher than that of cell without the buffer layer. As expected, the series resistance of the cell increases with the incorporation of the buffer layer while, remarkably, the shunt resistance is practically not modified. This means that the effect of the buffer incorporation is not related to the elimination of micro short-circuits or leakage currents which should be present in this type of UT cell. Rather, the buffer layer impacts the Voc and Isc as noticed above. The influence of the front contact on the Voc for CdTe cells has been empirically suggested [18] but the reason of this influence is not completely clear. It is speculated that the contribution of the $\mathrm{u}-\mathrm{SnO}_{2}$ buffer layer is related to the passivation of the $\mathrm{SnO}_{2} / \mathrm{CdS}$ interface and the consequent reduction of the recombination in this region. This should favor the increase in both Isc and Voc as was observed. It cannot be excluded that the $\mathrm{u}-\mathrm{SnO}_{2}$ buffer also promotes a better band alignment in the structure or helps block impurities diffusion from the TEC-15 substrate, as it has been reported in the literature $[19,20]$. 


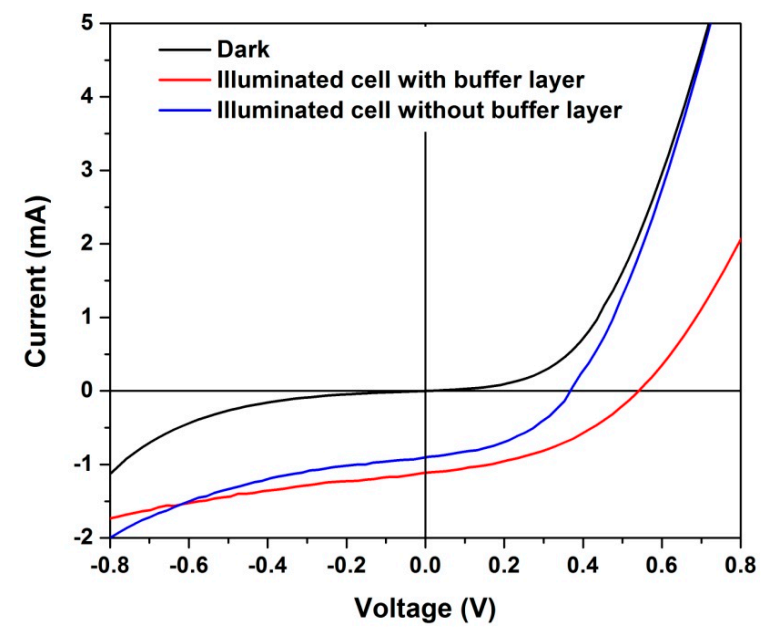

Figure 7. Dark and illuminated I-V curves of the heterostructures.

Table 1. Extracted PV parameters from the I-V curves of the CdS/CdTe devices.

\begin{tabular}{|c|c|c|c|c|c|c|}
\hline Samples & $\begin{array}{l}\text { Voc } \\
(\mathrm{mV})\end{array}$ & $\begin{array}{c}\mathrm{Jsc} \\
\left(\mathrm{mA} / \mathrm{cm}^{2}\right)\end{array}$ & $\begin{array}{l}\text { FF } \\
(\%)\end{array}$ & $\begin{array}{c}\eta \\
(\%)\end{array}$ & $\begin{array}{l}\text { Series Resistance } \\
\qquad\left(\Omega \mathrm{cm}^{2}\right)\end{array}$ & $\begin{array}{l}\text { Shunt Resistance } \\
\left(\Omega \mathrm{cm}^{2}\right)\end{array}$ \\
\hline Without buffer layer & 369 & 11.3 & 43.2 & 2.1 & 2.9 & 97.8 \\
\hline With buffer layer & 542 & 13.9 & 41.1 & 3.7 & 5.4 & 95.7 \\
\hline
\end{tabular}

\section{Conclusions}

Individual layers of undoped $\mathrm{SnO}_{2}, \mathrm{CdS}$, and CdTe with thickness and optical transmission adapted to operate in UT solar cells were obtained by RF sputtering. These layers were characterized and successfully incorporated into heterostructures with relatively abrupt interfaces and good surface coverage. Solar cell devices were fabricated with these heterostructures which shown reasonable photovoltaic parameters, especially if it is taking into account that many device related parameters were not properly optimized. For example, thermal treatment in $\mathrm{CdCl}_{2}$ or contact annealing should be further optimized with the aim of obtaining more efficient devices. In this work, it was clearly observed that the inclusion of an undoped $\mathrm{SnO}_{2}$ buffer layer led to an appreciable increase of the open circuit voltage and a moderate increase in the Isc. The increase in series resistance caused by the introduction of the additional layer is more than compensated by the Voc and Isc increases. Overall, the efficiency of the cell improved from $2.1 \%$ to $3.7 \%$. These changes promoted by the buffer layer are probably due to passivation effects of the $\mathrm{SnO}_{2} / \mathrm{CdS}$ interface, blocking of diffusion impurities from the substrate or to improvement of the band alignment.

Supplementary Materials: The following are available online at http://www.mdpi.com/1996-1944/11/10/ 1788/s1, Figure S1: Growth rate determined for each material. (a) $\mathrm{u}-\mathrm{SnO}_{2}$ and $\mathrm{CdS}$, and (b) CdTe; Figure S2: Transmission spectra for the CdTe layer and the heterostructures with and without buffer layer studied in this paper; Figure S3: Histograms of the grain size values in each layer.

Author Contributions: Conceptualization, G.C.-P.; Investigation, K.G.Z-B, P.G.Z.-B., F.d.M.-F. and J.S.-H.; Methodology, J.A.A.-A., L.A.M.-R., H.M.-G. and S.G.; Supervision, O.d.M. and G.C.-P.; Writing-original draft, K.G.Z.-B.; Writing-review and editing, O.d.M. and G.C.-P.

Funding: This research received no external funding.

Acknowledgments: The authors gratefully acknowledge project SIP-20170135, SIP-20180374 and CONACyT-SENER project P37. O.d.M. thanks the support of UNAM/DGAPA/PREI program. The authors also thank G. Santana for fruitful discussions regarding the interpretation of the solar cell characterization measurements.

Conflicts of Interest: The authors declare no conflict of interest. 


\section{References}

1. Gessert, T.A.; Wei, S.H.; Ma, J.; Albin, D.S.; Dhere, R.G.; Duenow, J.N.; Kuciauskas, D.; Kanevce, A.; Barnes, T.M.; Burst, J.M.; et al. Research strategies toward improving thin-film CdTe photovoltaic devices beyond 20\% conversion efficiency. Sol. Energy Mater. Sol. Cells 2013, 119, 149-155. [CrossRef]

2. First Solar Press Release, First Solar Builds the Highest Efficiency Thin Film PV Cell on Record, 5 August 2014. Available online: http://investor.firstsolar.com/news-releases/news-release-details/first-solarbuilds-highest-efficiency-thin-film-pv-cell-record (accessed on 15 August 2018).

3. Gupta, A.; Compaan, A.D. All-sputtered 14\% CdS/CdTe thin-film solar cell with ZnO:Al transparent conducting oxide. Appl. Phys. Lett. 2004, 85, 684-686. [CrossRef]

4. Dharmadasa, I.M.; Bingham, P.A.; Echendu, O.K.; Salim, H.I.; Druffel, T.; Dharmadasa, R.; Sumanasekera, G.U.; Dharmasena, R.R.; Dergacheva, M.B.; Mit, K.A.; et al. Fabrication of CdS/CdTe-Based Thin Film Solar Cells Using an Electrochemical Technique. Coatings 2014, 4, 380-415. [CrossRef]

5. Plotnikov, V.V.; Kwon, D.H.; Wieland, K.A.; Compaan, A.D. 10\% Efficiency Solar Cells with $0.5 \mu \mathrm{m}$ of CdTe. In Proceedings of the 34th IEEE Photovoltaic Specialists Conference, Philadelphia, PA, USA, 7-12 June 2009.

6. Bosio, A.; Rosa, G.; Romeo, N. Past, present and future of the thin film CdTe/CdS solar cells. Solar Energy 2018. [CrossRef]

7. Yadav, J.B.; Patil, R.B.; Puri, R.K.; Puri, V. Studies on undoped $\mathrm{SnO}_{2}$ thin film deposited by chemical reactive evaporation method. Mater. Sci. Eng. B. 2007, 139, 69-73. [CrossRef]

8. Papadopoulos, N.D.; Tsakiridis, P.E.; Hristoforou, E. Structural and electrical properties of undoped $\mathrm{SnO}_{2}$ films developed by a low cost CVD technique with two different methods: comparative study. J. Optoelectron Adv. M. 2005, 7, 2693-2706.

9. Fuchs, A.; Schimper, H.J.; Klein, A.; Jaegermann, W. Photoemission studies on undoped $\mathrm{SnO}_{2}$ buffer layers for CdTe thin film solar cells. Energy Procedia 2011, 10, 149-154. [CrossRef]

10. Sun Well Solar, Semitransparent Solar Cells Type. Available online: http://www.sunwellsolar.com (accessed on 13 June 2018).

11. Robertson, J. Electronic structure of $\mathrm{SnO}_{2}, \mathrm{GeO}_{2}, \mathrm{PbO}_{2}, \mathrm{TeO}_{2}$ and $\mathrm{MgF}_{2}$. J. Phys. C Solid State Phys. 1979, 12, 4767. [CrossRef]

12. Oliva, A.I.; Solís-Canto, O.; Castro-Rodríguez, R.; Quintana, P. Formation of the band gap energy on CdS thin films growth by two different techniques. Thin Solid Films 2001, 391, 28-35. [CrossRef]

13. Lalitha, S.; Sathyamoorthy, R.; Sundaram, S.; Subbarayan, A.; Natarajan, K. Characterization of CdTe thin film-dependence of structural and optical properties on temperature and thickness. Sol. Energy Mater. Sol. Cells 2004, 82, 187-199. [CrossRef]

14. Diéguez, A.; Romano-Rodríguez, A.; Vila, A.; Morante, J.R. The complete Raman spectrum of nanometric $\mathrm{SnO}_{2}$ particles. J. Appl. Phys. 2001, 90, 1550-1557. [CrossRef]

15. Hemley, R.J.; Mao, H.K.; Bell, P.M.; Mysen, B.O. Raman Spectroscopy of $\mathrm{SiO}_{2}$ Glass at High Pressure. Phys. Rev. Lett. 1986, 50, 747-750. [CrossRef] [PubMed]

16. Nusimovici, M.A.; Birman, J.L. Lattice dynamics of wurtzite: CdS. Phys. Rev. 1967, 156, 925-938. [CrossRef]

17. Frausto-Reyes, C.; Molina-Contreras, J.R.; Medina-Gutiérrez, C.; Calixto, S. CdTe surface roughness by Raman spectroscopy using the $830 \mathrm{~nm}$ wavelength. Spectrochim. Acta Part A 2006, 65, 51-55. [CrossRef] [PubMed]

18. Ferekides, C.S.; Morel, D.L. Process Development for High $V_{O C} C d T e$ Solar Cells; National Renewable Energy Lab. (NREL): Golden, CO, USA, May 2011.

19. Ganguly, G.; Carlson, D.E.; Hegedus, S.S.; Ryan, D.; Gordon, R.G.; Pang, D.; Reedy, R.C. Improved fill factors in amorphous silicon solar cells on zinc oxide by insertion of a germanium layer to block impurity incorporation. Appl. Phys. Lett. 2004, 85, 479-481. [CrossRef]

20. Mamaua, R.; Balasabramanian, U.; Gayam, S.; Bapanapalli, S.; Nemani, L.; Jayabal, M.; Zhao, H.; Morel, D.L.; Ferekides, C.S. The Influence of Various Front Contact Materials on the Performance of CdTe Solar Cells. In Proceedings of the Conference Record of the Thirty-First IEEE Photovoltaic Specialists Conference, Lake Buena Vista, FL, USA, 3-7 January 2005; pp. 283-286.

(C) 2018 by the authors. Licensee MDPI, Basel, Switzerland. This article is an open access article distributed under the terms and conditions of the Creative Commons Attribution (CC BY) license (http://creativecommons.org/licenses/by/4.0/). 